\title{
SIX1 Gene
}

National Cancer Institute

\section{Source}

National Cancer Institute. SIX1 Gene. NCI Thesaurus. Code C84410.

This gene may be involved in limb development. 